\title{
Research on Cultivation of Students' Translation Ability under Interactive Teaching Model
}

\author{
Huiqin Ning ${ }^{1, a}$ \\ ${ }^{1}$ Nanyang Institute of Technology, Nanyang, 473000, China \\ ${ }^{\mathrm{a}}$ email
}

Keywords: Translation ability, Interactive Teaching model, Interactive translation

\begin{abstract}
Interactive teaching model is a teaching model based on Constructivism Theory. The interactive teaching model emphasizes that teachers should try to make positive interaction between teachers and students as well as students and students. The application of interactive teaching model in English translation teaching is conducive to the improvement of students' translation ability. This paper analyzes the concept, characteristics and functions of interactive teaching, and gives the interactive models of pre-class interaction, during-class interaction and after-class interaction in translation teaching to provide some references for college English teachers.
\end{abstract}

\section{Introduction}

Translation competence is composed of the translator's translation knowledge, translation ability and translation strategy. The translation skills include the translator's cultural discrimination ability, language ability, language analysis and pragmatic bidirectional conversion and expression ability and aesthetic judgment and expression ability and logical analysis and correction ability of translation competence is a multidimensional concept, it consists of a series of interrelated factors, is a comprehensive ability to use the language, the translator of the language knowledge, cultural knowledge and other fields of knowledge and master the ability to use, which we usually refer to reading, writing and translation abilities. With the deepening and development of economic globalization, international communication is becoming more and more frequent, and practical translation talents are more and more popular among all walks of life. There is a growing demand for translation talents in all walks of life, and the demands and expectations of translation talents are getting higher and higher. Traditional English translation teaching emphasizes knowledge transfer and less ability training, which cannot meet the requirements and expectations of the society for translation talents. Therefore, the mode of translation teaching to improve the students' practical translation ability, cultivate more able to adapt to the social progress and economic development, in line with the qualified translation talents of social demand, to solve the contradiction between demand and supply, has become an urgent problem in translation teaching and urgent task. The interactive teaching model is based on the theory of constructivism, and it also adopts a valuable teaching model developed from the theory of developmental psychology. Therefore, the interactive translation teaching model based on Constructivism emerges as the times require. This paper applies the interactive teaching model of Constructivism to English translation teaching in order to improve students' translation ability.

\section{Concept, Features and Functions of Interactive Teaching Model}

Concept of Interactive Teaching Model. Interactive teaching is a kind of creative teaching theory and strategy. The purpose is through dialogue and discussion between teachers and students, all aspects of the organization of teaching, teachers play a leading role in teaching. To achieve two-way communication and interaction between teachers and students, students and students: the interactive teaching method to students as the center, to create a real dialogue context, the whole process to enable students to participate in teaching activities, so that students take the initiative to actively construct knowledge in the scene and dialogue, fully excavate students' learning potential, 
arouse their initiative and creative, activate the interest of exploring the unknown: open classroom interactive teaching mode advocated innovative initiative, interactivity, The characteristics of openness. Network and multimedia teaching method is introduced, the mode of classroom teaching into classroom teaching and computer models to enhance classroom teaching information, interesting and practical world, unlimited learning resource to activate students' open innovation, divergent thinking, provide a multidimensional way to acquire knowledge for its. Inspired by teachers under the guidance of the students from passive to active thinking, thinking, teaching methods to break the stereotype shackles, make thinking potential play a positive and sustainable development: the three components of the interactive teaching mode from teaching subject, teaching environment and the interaction between them, the formation of mutual influence and mutual promotion of the organic whole. This new kind of teaching model adapting to the fierce market competition environment, based on modern teaching theory as the guiding ideology, comprehensive use of various teaching resources and means, through the interaction of multi-dimensional interactive teaching methods, stimulate the potential, enhance the value of teaching.

Features of Interactive Teaching Model. In the process of translation teaching, teachers should fully understand the characteristics of Interactive English translation teaching mode, let the students give full play to their initiative and creativity, learning and translation practice combined with translation theories, promote student's all-round development in listening and speaking, reading and writing, five kinds of ability, improve the comprehensive the level of the students. Interactive English teaching should be guided by language learning theory and differentiated and targeted teaching should be carried out. Teachers should teach students after they fully understand the characteristics of students. Adopting diversified teaching methods to make translation teaching more interesting can attract students' attention and improve students' interest in learning. In short, interactive features of English translation teaching mode is summed up to improve the interaction and communication between teachers and students; to pay attention to the actual situation of students, the level of translation, and according to the actual situation as the basis for teaching. Richness has strengthened the introduction of extracurricular translation materials, enriched the teaching content, innovative and various teaching modes, and attracted the attention of students. The characteristic of Interactive English teaching is the main reason to improve the efficiency of English translation teaching. As a theoretical basis, interactive translation teaching model emphasizes the construction of students' translation knowledge and skills rather than the leading role of teachers. Teachers to change the traditional What I say goes., learning initiative to students, for students to create a conducive to the students to construct new knowledge environment. The creation of the environment includes both the creation of the context and the construction of the text data. Students construct new knowledge system by using their own knowledge in the environment created by teachers. In this teaching mode, in addition to the two main bodies of teachers and students, it also needs some auxiliary means to help students build the proper knowledge system.

Functions of Interactive Teaching Model. Interactive language teaching design and teaching activities should be student-centered, fully mobilize the enthusiasm of learning, interactive form, teaching approach and teaching practice of teacher-student interaction, teaching objective and teaching activities, listening speaking reading and writing interaction, and to construct the vivid teaching situation. Translation teaching should take the student as the center, the use of interactive language teaching method: according to the theory of constructivism, interactive translation teaching translation in accordance with the cognitive law of students, students are the subject of translation teaching, translation skills and knowledge through students' active construction rather than by teachers instill translation knowledge acquired; the teacher's role is to guide and construct all kinds of knowledge and skills to promote students' translation. The study of translation process is a collaborative interaction between teachers and students, which not only can promote the construction of knowledge and skills, but also to create a relaxed and pleasant learning environment to stimulate students' learning enthusiasm, initiative and innovation. Therefore, teachers should encourage more students to participate in all aspects of translation teaching, design questions, group discussions, lectures, seminars, etc. of rich and colorful classroom activities, students in the process of teachers 
and students, students in collaboration with ease, to find and use bilingual conversion laws, cultivate correct translation thinking habits, promote the students' knowledge and skills to enhance the translation. Extracurricular interactive translation teaching can provide mutual cooperation, mutual communication and exchange opportunities for teachers and students, help between teachers and students, students and students to construct the relationship of equality, mutual trust, sharing, stimulate students desire for knowledge, make students change from passive learning to active learning, the creative get better development in a natural, open, without time and space constraints interactive environment, help students translation ability and raise the level of translation.

\section{Translation Ability Cultivation Based on Interactive Teaching Model}

Interaction to Cultivate Translation Ability before Class. The interactive teaching mode applied in English translation teaching, teachers should change their teaching ideas, to redefine their role, is teaching teacher centered into student-centered. On this basis, there should be reasonable and effective classroom teaching design. First, to fully understand the students, do a good job of pre-class communication with students. Before each semester, teachers should establish communication between teachers and students and teach the class of students, through this communication existing foundation and learning for the students are expected to have a full understanding, and decide for their teaching. Secondly, before class, arrange the preview content for students. They can design some questions for each student before they teach new knowledge, and ask the students to think carefully or collect relevant materials before class. In the teaching can introduce the film and television content, such information can cause the student's interest, lets the student in watching the movie and television play process, carries on the translation training. The interesting stories in film and television play can attract students, let students understand the western culture in a relaxed and happy process, and improve translation ability. For example, before teaching the translation skills of English and Chinese idioms, the teacher can ask students to think carefully before class, suitable for students to discuss, but also can be used as a topic for discussion, ask students to discuss in class. The translation course is a very practical course, network interaction and classroom interaction while providing a platform for students to experience the process of translation, but to obtain direct experience of translation also must rely on the real translation project, create a real environment for many translation practice and training of students. The creation of authentic translation environment must be mediated by authentic translation projects. The purpose is to cultivate students' practical translation ability through the interaction between teachers and students and the translation market.

Interaction to Cultivate Translation Ability during Class. The main duties of teachers is inspire guide and help students solve students' understanding in the text on the problem, gradually realize the teacher led classroom to students led the transformation of classroom student led classroom is to autonomous learning as the core, teaching activities with strong autonomy and cooperative discussion type teaching form to carry out interactive the classroom should be a combination of explanation and demonstration of classroom learning in the classroom, a combination of classroom and extracurricular learning, change the traditional teaching methods, the use of multimedia to enrich teaching form. Using the Internet, extra-curricular teaching can be more convenient, such as the establishment of translation groups, network communication platform, teachers' Extra-curricular information sharing, etc., can be effectively realized. Teachers ask questions to students effectively. Effective questioning is a teaching method which is often used by teachers to promote the interaction between teachers and students and students. Effective questioning is the teacher in the teaching process according to the needs of teaching, targeted to students and put forward some instructive problems related to teaching content, stimulate students' learning emotion and enthusiasm of independent inquiry, the attention of students into classroom teaching tasks. Effective questioning in teaching can promote the interaction between teachers and students, students and students. Through questioning and judging in class, the interaction between teachers and students in classroom is formed, and the classroom atmosphere is activated, and good teaching effect can be obtained. Secondly, organize students to carry out group discussions in class. Group discussion is an 
important part of interactive teaching. Through the discussion, students can further expand their own ideas, can be more scattered knowledge and systematization of knowledge. In the process of group discussion, teachers must play the role of organizer, guider and guider.

Interaction to Cultivate Translation Ability after Class. Translation is a highly practical course, which requires students to have a great deal of translation practice after class. First, teachers can make full use of multimedia and network technology to increase the extracurricular communication between themselves and students. The layout of this translation task, still use the classroom discussion, students are required to take the group as the unit, to discuss and communicate between team members, learn from each other during the process of translation problems and their experiences. The teacher should judge the students' discussion, or unify the questions and answers to the students. Secondly, teachers can study or practice on students' translation experience and insights published on his personal website or micro-blog for students to learn. When teachers give their experience or insights to students, they can ask the students to comment on them, and even ask questions about the teacher's views and interact with the teachers. In this way, students can gradually form their own translation knowledge system and translation ability in the interaction with teachers. Again, teachers can also set up a network of extracurricular translation classroom for students, the famous translation or translation of new ideas and new methods in this class to be introduced to the students, or recommend the student to the translation and translation of the book of the latest newsletter. The students' timely and continuous understanding of the latest developments in translation from the teachers will also help them build their own translation knowledge system more quickly. Teachers after each group show, summarize and guide to find out the problems of students there, let students discuss, think deeply and then, after the teacher let the student carry on analysis and discussion, students' opinions and their comprehensive knowledge, for students to solve difficult problems.

\section{Conclusion}

As a new teaching method, interactive English teaching mode plays a very important role in improving the quality of English translation teaching in china. In English teaching, English teachers should fully understand the characteristics of the interactive teaching mode, constructing practical teaching mode of students, realize the interactive teaching mode in the application of English translation teaching Chinese. Interactive English translation teaching conforms to the characteristics of contemporary students, and helps schools cultivate comprehensive talents to meet the needs of the society and market.

\section{References}

[1] Gao Mei. Exploration on the Construction of "Interactive" Teaching Mode for English Translation [J]. Value Engineering, 2016, 35(20): 178-180.

[2] Zhang Linying. Training of Students' Translation Ability under Interactive Translation Teaching Model [J]. Journal of North China University of Science and Technology (Social Science Edition), 2017, 17(1): 114-118.

[3] Wang Li, Dai Jianchun. The Construction and Application of the WeChat-Based Mobile Interactive Translation Teaching Model [J]. Technology Enhanced Foreign Language Education, 2015(162): 35-41.

[4] He Hongli. On Construction of Interactive Mode of Translation Teaching in Information Age [J]. Journal of Hengyang Normal University, 2015, 36(4): 148-151. 